Bryn Mawr College

Scholarship, Research, and Creative Work at Bryn Mawr College

\title{
A Refugee Scholar from Nazi Germany: Emmy Noether and Bryn Mawr College
}

Qinna Shen

Bryn Mawr College, qshen@brynmawr.edu

Follow this and additional works at: https://repository.brynmawr.edu/german_pubs

Part of the German Language and Literature Commons

Let us know how access to this document benefits you.

\section{Custom Citation}

Shen, Qinna. 2019. "A Refugee Scholar from Nazi Germany: Emmy Noether and Bryn Mawr College." The Mathematical Intelligencer, 41.3: 1-14.

This paper is posted at Scholarship, Research, and Creative Work at Bryn Mawr College.

https://repository.brynmawr.edu/german_pubs/19

For more information, please contact repository@brynmawr.edu. 


\section{A Refugee Scholar from Nazi Germany: Emmy Noether and Bryn Mawr College}

\section{Qinna Shen $(\mathbb{0}$}

It is everywhere incumbent upon university faculties ... to maintain their historic duty of welcoming scholars, irrespective of race, religion and political opinion, into academic society, of protecting them in the interest of learning and human understanding, and of conserving for the world the ability and scholarship that might otherwise disappear.

(1) n April 7, 1933, 2 months after Hitler came to power, the new Civil Service Law barred non-Aryan Germans, including university professors and researchers of Jewish descent, from working in the public sector. The Institute of International Education, which was founded in New York in 1919, quickly responded by establishing the Emergency Committee in Aid of Displaced German Scholars in June 1933. The committee's mission was to place those suddenly unemployed and imperiled academics in institutions outside of Germany. At the time, the otherwise restrictive U.S. immigration laws made an exception for professors and ministers who had been invited to work at American institutions. It was this provision that enabled the Emergency Committee to help over three hundred refugee scholars. But not all American institutions were receptive to calls from the Emergency Committee. According to Laurel Leff, a professor of journalism at Northeastern University who has been leading a project called "Rediscovering the Refugee Scholars," some colleges, such as Hamilton College, explicitly told the Emergency Committee they wanted an Aryan applicant. Dartmouth College offered to take someone of Jewish heritage, but stipulated that the candidate "shouldn't seem too Jewish." It was clear that "antiGerman sentiment and anti-Semitism reigned on many campuses." ${ }^{2}$ Bryn Mawr College, however, along with

\footnotetext{
${ }^{1}$ Lorraine Boissoneault, "The Forgotten Women Scientists Who Fled the Holocaust for the United States: A New Project from Northeastern University Traces the Journeys of 80 Women who Attempted to Escape Europe and Find New Lives in America during World War II." https://www.smithsonianmag.com/history/forgottenwomen-scientists-who-fled-holocaust-united-states-180967166/. See also the Northeastern University team project "Rediscovering the Refugee Scholars of the Nazi Era." https://www.northeastern.edu/refugeescholars/home.

${ }^{2}$ Miriam Intrator, "Jewish Refugee Scholars in America: Some European Academics Escaped to America before the Holocaust." https://www.myjewishlearning.com/ article/jewish-refugee-scholars-in-america/.
} 
many other American and foreign institutions, welcomed refugee scholars into its midst. Marion Edwards Park, who served as president of Bryn Mawr from 1922 to 1942 and steered it through the Great Depression, the rise of fascism in Europe, and the beginning of the Second World War, was an early member of the Emergency Committee. Under her extraordinary and judicious leadership, the small women's college hosted a number of refugee scholars, beginning with the acclaimed mathematician Emmy Noether (1882-1935).

In this article, I explore Bryn Mawr College's involvement with the Emergency Committee by examining the case of its most prominent guest, Emmy Noether. I pieced together discoveries from archives and existing publications to reconstruct a coherent story of the last two years of her life, which she spent at Bryn Mawr after she was dismissed from the University of Göttingen. Whereas Noether's earlier life and work in Erlangen and Göttingen are well documented, ${ }^{3}$ many of the materials concerning her emigration and time at Bryn Mawr had not been collected and organized. My essay will give readers a glimpse into what this small women's college did in those critical years to rescue and sustain purged scholars, a topic of great interest in recent years. ${ }^{4}$

\section{The Mission of the Emergency Committee}

The Great Depression, whose global effects enabled the rise of fascism in Germany and thus helped to set the stage for the exodus of Jewish scholars, also complicated the task of the Emergency Committee that was formed to rescue them. From the outset, the committee made clear that due to the failing economy, American universities "are suffering from severe deprivation" and "teachers have been dropped from the rolls," and therefore "the universities must not be called upon for financial assistance for the benefit of foreign scholars." 5 The Emergency Committee's approach was to match an émigré scholar with an American university that was willing to provide the scholar with a position. Then, using funds provided by the Emergency Committee, the Rockefeller Foundation, and other philanthropic institutions, the university would pay the new faculty member's salary.
In the early years, the committee was able to offer institutions annual grants of $\$ 2,000$ for two years; the Rockefeller Foundation matched the committee's grant, and in some cases gave even more. However, as an increasing number of European countries fell to the Nazis and more scholars were dismissed, the committee had to reduce the amount to around $\$ 1,000 .^{6}$ In 1938 , the committee changed its name to reflect the changing demographic reality, becoming the Emergency Committee in Aid of Displaced Foreign Scholars. ${ }^{7}$

On July 3, 1933, the head of the Emergency Committee, Edward R. Murrow, wrote to inform President Park that the committee had granted the sum of $\$ 2,000$ for the support of a German scholar to be chosen by Bryn Mawr. He suggested that Bryn Mawr seek additional financial support from the Rockefeller Foundation (Fig. 1). The college elected to invite Emmy Noether, and one month later the Rockefeller Foundation confirmed that it

would contribute $\$ 2,000$ toward the salary of Dr. Noether during the academic year 1933-1934 at Bryn Mawr College ... This grant, of course, applies only to Dr. Noether, and will lapse if she cannot accept. ${ }^{8}$

The reasoning behind the decision by the small liberal arts college to offer refuge to a world-class research mathematician is not immediately clear. Why did Bryn Mawr choose Noether, and why did Noether accept the school's offer?

\section{From Germany to the United States}

Emmy Noether was fifty-one years old when her academic career in Germany was cut short by the anti-Semitic Civil Service Law. She had been born into a Jewish family on March 23, 1882, in Erlangen, Germany, and, against all odds, received her doctoral degree in mathematics from Erlangen in 1907, becoming the first German woman to receive a Ph.D. in mathematics in Germany. ${ }^{9}$ Her groundbreaking research impressed Felix Klein and David Hilbert at Göttingen, a hub of mathematical research, who then invited her to join the Göttingen faculty in 1915. Despite discrimination against women in German academia,

\footnotetext{
${ }^{3}$ See, for example, Auguste Dick, Emmy Noether, 1882-1935, translated by H. I. Blocher, Boston: Birkhäuser (1981); James W. Brewer and Martha K. Smith, eds. Emmy Noether: A Tribute to Her Life and Work, New York and Basel: Marcel Dekker (1981); and Margaret B. W. Tent, Emmy Noether: The Mother of Modern Algebra, Natick, MA: A K Peters, Ltd. (2008).

${ }^{4}$ Many efforts have of course already been made in this regard. See, for example, Reinhard Siegmund-Schultze, Mathematicians Fleeing from Nazi Germany: Individual Fates and Global Impact, Princeton University Press (2009); Mitchell G. Ash and Alfons Söllner, eds., Forced Migration and Scientific Change: Émigré German-Speaking Scientists and Scholars after 1933, Cambridge University Press (1996); Catherine Epstein, A Past Renewed: A Catalog of German-Speaking Refugee Historians in the United States after 1933, Cambridge University Press (1993); Richard Bodek, et al. The Fruits of Exile: Central European Intellectual Immigration to America in the Age of Fascism, University of South Carolina Press (2010). The Mathematical Intelligencer has also published a number of related articles, for example, Vol. 37, No. 1 (2015) is largely the proceedings of the symposium Turmoil and Transition: Tracing Émigré Mathematicians in the Twentieth Century, which was held at New York University on October 1, 2013, on the opening of the major international exhibition Transcending Tradition: Jewish Mathematicians in German-Speaking Academic Culture; see Moritz Epple, "An Introduction to the Exhibition," Mathematical Intelligencer 37:1 (2015), 5-9; see also the review of the exhibition catalogue by Marjorie Senechal in Notices of the AMS (February 2013) 209-213. Reinhardt Siegmund-Schultze's article about the Rockefeller program, "Rockefeller Philanthropy and Mathematical Emigration between World Wars," Mathematical Intelligencer 37:1 (2015), 10-19, could be read together with my article.

${ }^{5}$ The Emergency Committee in Aid of Displaced German Scholars, Livingston Farrand, chairman; Fred M. Stein, treasurer; Stephen Duggan, secretary. Bryn Mawr Special Collections.

${ }^{6}$ The Emergency Committee. Report of June 1, 1941, by Stephen Duggan.

${ }^{7}$ Utz Maas, Verfolgung und Auswanderung deutschsprachiger Sprachforscher 1933-1945, Osnabrück: Secolo Verlag (1996) 36.

${ }^{8}$ See 3 H Noether, Emmy. Correspondence, President's Office, about E. Noether 1933-1935, Bryn Mawr Special Collections.

${ }^{9}$ Dick, 96.
} 
INSTITUTE of INTERNATIONAL EDUCATION, INC. TWO WEST FORTY-FIFTH STREET - NEW YORK CITY

VANDERBILT 3 - 1924

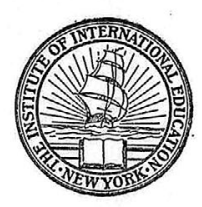

STEPHEN DUGGAN, Ph.D., LL.D.

EDWARD R. MUURROW
ASSISTANT DIRECTOR ASSISTANT DIRECTOR MARY L. WAITE CABle AdDRess "InTERed"

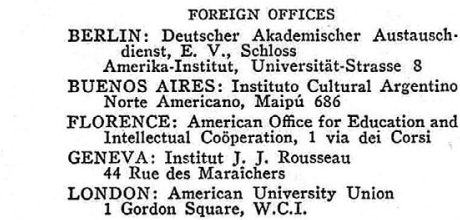

LONDON: American University Union
1 Gordon Square, W.C.I.

\section{BOARD OF TRUSTEES}

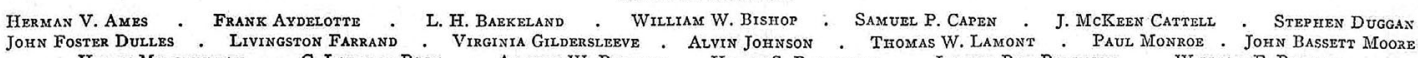

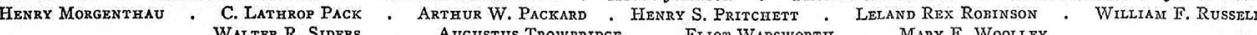

\author{
MADRID: Junta para Amplaiación de Estudios
Duque de Medinaceli 4 \\ PARIS: American University Union \\ PRAGUE: The American Institute \\ VIENNA. Anstros \\ VIENNA: Austro-Ara \\ ZURICH: Professor Arthur Rohn, President \\ Swiss School Council . Ris
}

Technische Hochschule

July 3, 1933

President Marion Parix

Bryn Nawr College

Pennsylvania

My dear President Paxix:

Professor Duggan has instructed me to inform you of recent action taken by the imergency Committee in Aid of Displaced German Scholars, of which he is secretary.

The Bmergency Committee has eranted the sum of $\$ 2,000$ to Bryn Mavr for the support of a German scholar to be chosen by you. The grant is made on the assumption that you will desire to offer the German scholar selected a salary of aporoximately $\$ 4,000$ a year. The balance necessary to complete this amount may be raised from any available source, but the committee suggests that you commicate immediately with the Rockefeller Foundation. 61 Broadway, New York, N. Y., informing them of the grant made by the Emergency Committee and formally requesting a sum sufficient to meet the balance.

According to the procedure adopted by the Bmergency Committee, invitations are to be issued directly by the institution. Till you therefore please indicate to us at an early date the name of the German scholer to whom you are extending an invitation. In the event that your first choice is for any reason unable to accept, the committee will consider making the above-mentioned grant of $\$ 2,000$ for a. orotessor chosen by you to reolace him.

The funds at present available permit us now to orant assistance for one professor only for a period of one year. It is hoped that additional funds will be forthcoming and if such is the case apolications for $a$ renewal of this grant for a period. of one year more will be considered. It is hoped al so that the adoitional funds expected will allow of other professors being invited.

The offices of the Emergency Comittee are at your disposal if you desire assistance in any way in completing arrangements with the professor chosen by you.

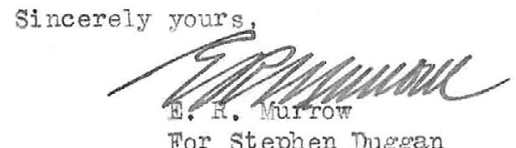

Figure I. The Emergency Committee's grant letter to Bryn Mawr College (courtesy of Bryn Mawr Special Collections). 
Noether gained a growing reputation in her field as a leading expert in modern algebra and developed a large following, the so-called "Noether boys," who came from many different countries, including China and Japan, to study with her. ${ }^{10}$ During her time at Göttingen, Noether collaborated closely with Hermann Weyl and became acquainted with many first-rate mathematicians, including Solomon Lefschetz, from Princeton University, who was in Göttingen in the summer of 1931, and Oswald Veblen, from the Institute for Advanced Study (IAS), who was in Germany in 1932. These German and American colleagues were later instrumental in helping Noether go to Bryn Mawr and the IAS.

On April 13, 1933, Noether was among the very first academics to be dismissed, together with Max Born, Richard Courant, and three other Jewish professors. ${ }^{11}$ Many colleagues and eminent mathematicians wrote petition letters on behalf of Noether, including Helmut Hasse, Bartel Leendert van der Waerden, and Hermann Weyl. ${ }^{12}$ The chief administrator (Kurator) of Göttingen, J. T. Valentiner, however, refused to endorse her. On August 7, 1933, he wrote to the Ministry of Science, Art, and Education of the People in Berlin that Noether's sympathy for Marxist worldviews was so strong that she could not be regarded as a wholehearted supporter of the German state. ${ }^{13}$ Weyl later reminisced in his obituary of Noether, "I suppose there could hardly have been in any other case such a pile of enthusiastic testimonials filed with the Ministerium as was sent in on her behalf. At that time we really fought; there was still hope left that the worst could be warded off. It was in vain." ${ }^{14}$ Weyl, who succeeded Courant as director of the Göttingen Mathematical Institute, then immediately got in touch with Princeton University to arrange a visiting lectureship for Noether. He himself went on a lecture tour in the United States in October 1933 and stayed in Princeton. Veblen and the founding director of IAS, Abraham Flexner, welcomed Weyl and Albert Einstein to Princeton. The four dedicated themselves to finding and creating positions for their colleagues, especially those from Nazi Germany. Apparently the negotiations with Princeton regarding Noether fell through; as she later said, Princeton was at that time a "men's university, which admits nothing female" („Männer“-Universität, die nichts Weibliches zuläßt). ${ }^{15}$ However, a small women's college, conveniently located just a couple of hours by train from Princeton, shortly emerged as an attractive alternative to the "men's university."

Salomon Lefschetz, from Princeton, who knew Noether personally from his time in Göttingen, approached Anna Pell Wheeler (1883-1966), the chair of the mathematics department at Bryn Mawr, and suggested that the college take advantage of the Emergency Committee's offer to President Park to sponsor a refugee scholar by inviting Noether for the coming academic year. ${ }^{16}$ Bryn Mawr at that time was also the only women's college with a doctoral program in mathematics. On August 4, 1933, through the generosity of the Emergency Committee and the Rockefeller Foundation, the college was able to offer Noether a salary of $\$ 4,000$ (the equivalent of over $\$ 76,000$ today) to "carry on research work and consultation with advanced students" at Bryn Mawr during 1933-1934 (Fig. 2).

The draft of President Park's letter inviting Noether to Bryn Mawr contains a minor but interesting edit. She modified the statement that "The mathematical library is fairly good" to read, "The mathematical library contains the most important mathematical journals" (Fig. 3). The change suggests that President Park recognized that Bryn Mawr might not be the first choice of an academic of Noether's stature and sought to make the college more appealing. Indeed, Noether weighed other options both before and after receiving the offer from Bryn Mawr.

After being stripped of her hard-won lectureship, Noether initially hoped to find a position in Moscow through her friend and colleague Pavel S. Alexandrov. Alexandrov, president of the Moscow Mathematical Society, later recounted how he tried to assist her:

After her exile from Germany, she seriously considered finally settling in Moscow, and I had a correspondence with her on this question. She clearly understood that nowhere else were there such possibilities of creating a brilliant new mathematical school to replace the one that was taken from her in Göttingen. And I had already been negotiating with Narkompros about appointing her to a chair in algebra at Moscow University. But, as it happens, Narkompros delayed in making the decision and did not give me a final answer. Meanwhile time was

\footnotetext{
10“A Mathematician Almost Forgotten by His Country—[Chiungtze C. Tsen 曾畑之]” (一个几乎被国人遗忘的数学家) by an anonymous visiting scholar (July 9, 2006). http://bbs.creaders.net/education/bbsviewer.php?trd_id=172291\&language=big5.

${ }^{11}$ Dick, 75; Tent, 143-146.

12“Die Noether-Gutachten," Dokumente zu Emmy Noether, last updated on February 28, 2007, 7-29. https://www.mathi.uni-heidelberg.de/ roquette/Transkrip tionen/DOKNOE_070228.pdf.

13“"Der Kurator an den Minister, 7.8.1933," Dokumente zu Emmy Noether, 13.

${ }^{14}$ Hermann Weyl, "Emmy Noether: Memorial Address." In Dick, 112-152, here 132-133; Franz Lemmermeyer and Peter Roquette, eds., Helmut Hasse und Emmy Noether: Die Korrespondenz, 1925-1935, Universitätsverlag Göttingen (2006) 191, n 7.

${ }^{15}$ Lemmermeyer and Roquette, 204; "Emmy Noether's Paradise: How IAS Helped Support the First Female Professor in Germany When She Became a Displaced Refugee," by History Working Group, 2017. https://www.ias.edu/ideas/2017/emmy-noether\%E2\%80\%99s-paradise.

${ }^{16}$ Quoted from Kimberling, "Emmy Noether and Her Influence," In Brewer and Smith, 3-61, here 30. There were additional personal ties between Princeton and Bryn Mawr. Abraham Flexner's sister, Mary Flexner, attended Bryn Mawr with his financial support. Abraham Flexner's brother, Simon Flexner, was married to M. Carey Thomas's sister, Helen. M. Carey. Thomas was the first dean and second president of Bryn Mawr College. Simon Flexner was the first director of the Rockefeller Institute in New York. See "Abraham Flexner: Life." https://www.ias.edu/flexner-life; "Abraham Flexner." The Rockefeller Foundation: A Digital History. https:// rockfound.rockarch.org/biographical/-/asset_publisher/6ygcKECNI1nb/content/abraham-flexner?; Alice Digilio, "A Philadelphia Love Story," The Washington Post, February 19, 1984. https://www.washingtonpost.com/archive/entertainment/books/1984/02/19/a-philadelphia-love-story/41b5db3d-f8d4-4076-9946-a17b32d6d c50/?noredirect=on\&utm_term $=.251$ b416ce621.
} 


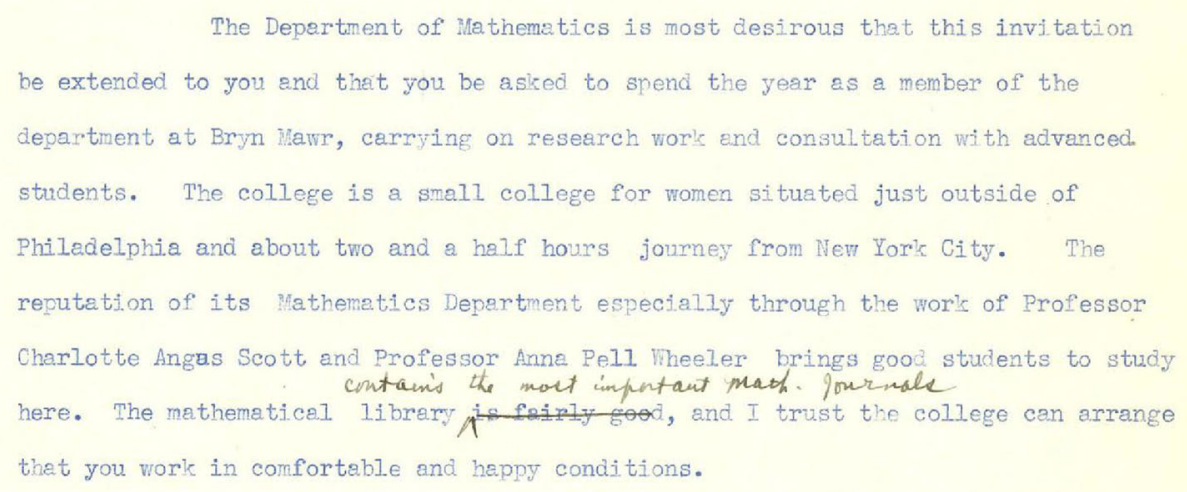

Figure 3. Draft of President Park's invitation to Noether (courtesy of Bryn Mawr Special Collections).

President Park on August 18, 1933, from Göttingen, Noether asked whether the appointment could be postponed for a year (Figs. 4 and 5).20 Noether wrote to Park in her native German, and indeed at this point no one at Bryn Mawr knew whether her English skills would allow her to interact with students in the mathematics department. The fact that she would be lecturing at Oxford-presumably in English-might have given Park some reassurance.

Park did not reply immediately, but Noether, unaware of the conditions set by the Emergency Committee and the Rockefeller Foundation, assumed that she would be able to delay her trip to America. A few weeks later, on September 7, 1933, she wrote to the director of the Mathematical Institute in Göttingen, Helmut Hasse, that for the winter term, she hoped to be in Oxford and believed that postponing the invitation from Bryn Mawr by one year should not be a problem. She added, "Bryn Mawr is, by the way, again a Frauen-College [i.e., a women's college, as is Somerville College], but as Veblen wrote me, the best of all women's colleges; and in addition so close to Princeton that I should go over often." ${ }^{21}$ On September 13, she described her options in a letter to her close colleague, Richard Brauer:

As for myself, I have been invited to lecture in Oxford for one term, I have chosen the one between Christmas and Easter. Subsequently, I was also offered a research professorship in Bryn-Mawr for 1933/34; I have asked to have it postponed for 1934/ 35 as I have already accepted the Oxford offer. I have no answer yet, but I think it should be alright ... Bryn Mawr is a women's college, but Mitchell [Howard Mitchell, professor of mathematics at the University of Pennsylvania] and others are there as professors; besides, Veblen has written to me that it is so close to
Princeton that they hope I will come over frequently. If through my postponement some funds became available, it could be perhaps somewhere else! By the way, I will live in a women's college in Oxford as well, but I shall lecture to the whole university, which is composed of the different colleges. ${ }^{22}$

At this point, Noether was still not eager to accept Bryn Mawr's offer and was in fact entertaining the hope that she might end up receiving a position "somewhere else."

When Helen Darbyshire, the principal of Somerville College, learned that Noether was negotiating with Bryn Mawr, she discouraged her from accepting a position at the college. Darbyshire cited her own unsatisfactory experience as a visiting professor at Wellesley College, and she painted a rosy picture of Noether lecturing at the University of Cambridge in the last term of the year after completing her term in Oxford. But she was unable to guarantee adequate compensation for Noether. H. M. Miller, an officer of the Rockefeller Foundation, reported on September 25 that Darbyshire "was not at all sure what action her College could take in finding funds to supplement the $₫ 24$ now available for N." ${ }^{23} 1$ week later-on the day before Bryn Mawr's fall semester began-Noether informed President Park of her decision to accept the offer without a deferral, and thus after months of drama, everything suddenly fell into place.

In retrospect, Noether's hesitation was certainly understandable; as Tent points out, "a primarily undergraduate college would certainly not have been her first choice." ${ }^{24}$ Noether may also have felt an obligation toward Oxford, since she had already agreed to lecture there. But she must have realized that from a practical point of view, Bryn Mawr was the more secure option, given the promise of at least one full year of salary with the possibility of renewal.

\footnotetext{
${ }^{20}$ The archival file contains the original letter in German along with the English translation reproduced here. See President's Office, about E. Noether.

${ }^{21}$ Lemmermeyer and Roquette, 199; my translation.

${ }^{22}$ The archival file contains the original letter in German along with the English translation reproduced here. See Noether, Emmy Transcriptions + Translations to English of Letter to R Brauer, Bryn Mawr Special Collections.

${ }^{23}$ Kimberling, "Emmy Noether and Her Influence," 30-31, citing a log submitted by Professor H. M. Miller to the Rockefeller Foundation's Paris office, dated September 25, 1933. According to Margaret Rainer, Oxford offered little support to refugee mathematicians from Germany during the 1930 s: "While several other universities saw the opportunity to assist refugees while bolstering their own academic profile ... nothing happened at Oxford beyond abortive negotiations for the great algebraist Emmy Noether to come to Somerville College on her dismissal from Göttingen." Rainer, "The 20th Century," in John Fauvel, Raymond Flood, and Robin Wilson, eds., Oxford Figures: Eight Centuries of the Mathematical Sciences, 2nd ed., Oxford University Press (2013) 315.

${ }^{24}$ Tent, 146-147.
} 


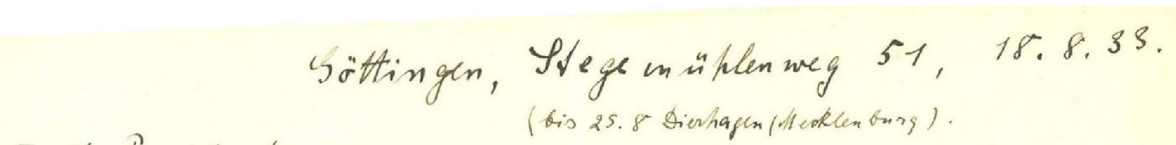

$$
\begin{aligned}
& \text { To the President Bryn Mawr College. } \\
& \text { Hy deon Q. Tark, } \\
& \text { ich danke Ihnen und dem Dollege, vor altem dem Depant. } \\
& \text { ment of Mathematios, oielmals firs das mis cibessa. } \\
& \text { schend angetatene Itipendium. Is war mis eine grafes } \\
& \text { Frende und ich werde es wit Vergnigen annchmen. } \\
& \text { Tch mufs allerdings um eine Verschietung um } \\
& \text { eim Yater bitten, anf das akaderninche Yahr 1934/35. } \\
& \text { iteen ich hoffe und vermute dafs das keine albar gaghen } \\
& \text { Tohwierigkeiten mochen wird. Sch hate naindith firs diesen } \\
& \text { binster, firs den Weiknachts- Oster. Term, schon sine Zim- } \\
& \text { ladung mach oxeford angenommen, in das Lomerville } \\
& \text { College, sus Gastvortesungen on der Universitait die anoh } \\
& \text { den Mathernatikern der andern. Colleges zugänglich rain } \\
& \text { maden. Sis un Reendigung dieser Voslesungen is } L \text { anch } \\
& \text { das akadernische jatu fast beendet. } \\
& \text { Cs ist mir persontioh ein sets angenctumes Gefinth } \\
& \text { schon fir wei Jatre im voras meine Tläne mathen. } \\
& \text { zu hämen; ich hoffe siohes dafp sich alles gut regets } \\
& \text { sind. } \\
& \text { there setre exgetene zanmy Woether. } \\
& \text { Sen Motalog habe ith mith suteresse gelesen. }
\end{aligned}
$$

Figure 4. Noether's original reply to President Park, requesting a one-year postponement (courtesy of Bryn Mawr Special Collections).

And the head of Bryn Mawr's mathematics department, Anna Pell Wheeler, had studied at Göttingen under Hilbert and Hermann Minkowski in 1906-1907 before acquiring her Ph.D. in 1910 from the University of Chicago. Noether could communicate with Wheeler in German, and visits to the IAS would provide Noether with the collegiality she had enjoyed in Göttingen and had expected to find at Oxford.

\section{Emmy Noether at Bryn Mawr}

At the opening of the academic year 1933-1934 on October 3, 1933, President Park announced Noether's impending arrival in her convocation address:

After a rapid fire of cables, I heard yesterday that we are to have a most distinguished foreign visitor ... in the faculty for the year, Dr. Emmy Noether, a member of the mathematical faculty of the University of Göttingen. Dr. Noether is the most eminent woman in mathematics in Europe and has had more students at Göttingen than anyone else in the department. With other members of the faculty, Dr. Noether was asked to resign from the University in the spring. To our great satisfaction the Institute of International Education and the Rockefeller Foundation have united in giving to the college a generous grant which makes it possible for the Department of Mathematics to invite her here for two years. Her general field is Algebra and the Theory of Numbers. Dr. Noether does not, I understand, speak English well enough to conduct a seminar at once but she will be available for consultation by the graduate students and later I 


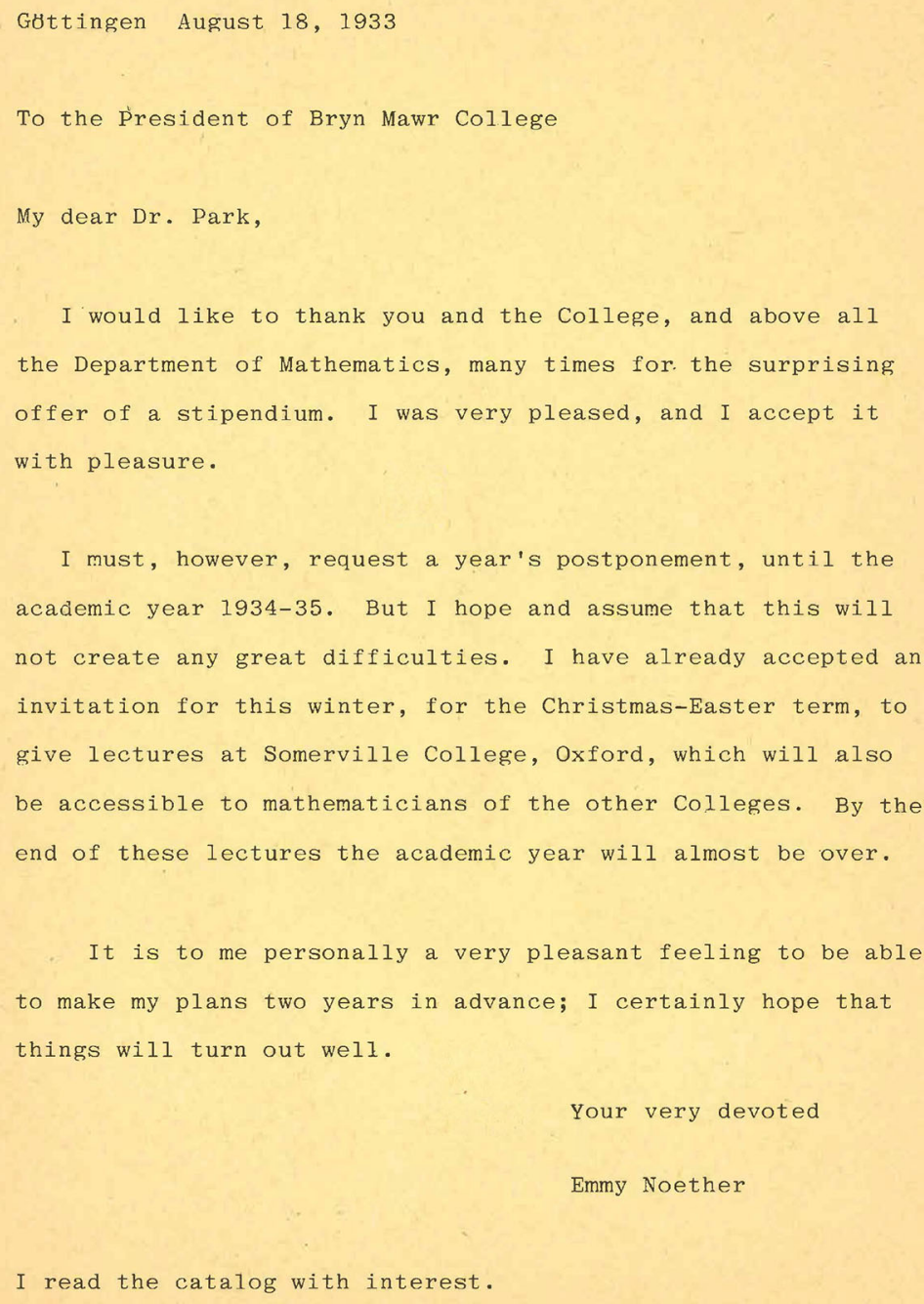

Figure 5. Noether's reply to President Park, requesting a one-year postponement (courtesy of Bryn Mawr Special Collections).

trust can herself give a course. I need not say that I am delighted Bryn Mawr College is one of many American institutions to welcome the scholars whose own country has rejected them. For the time only we must believe, Germany has set aside a great tradition of reverence for the scholar and for learning. I am glad also that the college can entertain so distinguished a woman and that the students in mathematics can profit by her brilliant teaching. ${ }^{25}$
In the original draft of her convocation speech, President Park noted that the Department of Mathematics had invited Noether "for one year certainly-I hope for a second as well." This phrase was penciled over and changed to "for two years" (Fig. 6). Since Noether did not agree to come until the day before the convocation, a second year of funding for Noether must have been secured sometime between the draft and the deliverance of the convocation speech. ${ }^{26}$ It is also to be noted that Park skipped over the

\footnotetext{
${ }^{25}$ See All Convocation Addresses by President Park, 1922-1942, Bryn Mawr Special Collections.

${ }^{26}$ Kimberling noted that after a flurry of correspondence, Warren Weaver, then director of the Division of Natural Sciences at the Rockefeller Foundation, wrote to assure President Park that "the Foundation may be counted on to contribute the sum of $\$ 2,000$ toward the salary of Prof. Noether at Bryn Mawr during the academic year 1934-1935," i.e., a second year of financial commitment from the Rockefeller Foundation toward Noether's salary. See Kimberling, "Emmy Noether and Her Influence," 31.
} 


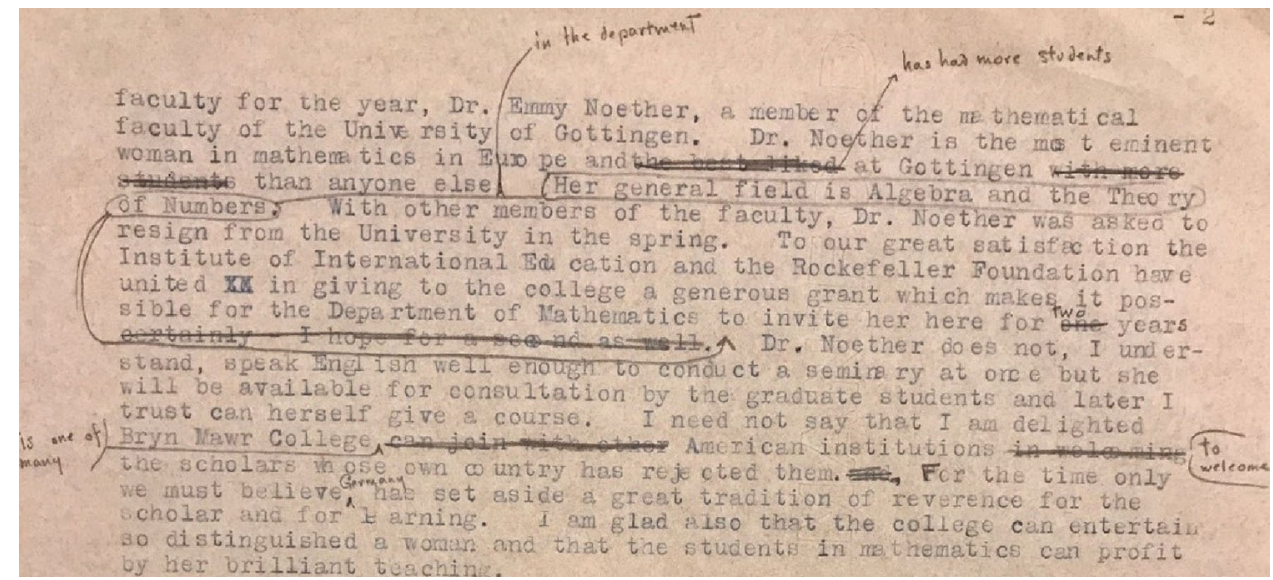

Figure 6. Draft of President Park's Convocation Speech in October 1933 (courtesy of Bryn Mawr Special Collections).

fact that Noether was Jewish and did not refer to the Emergency Committee per se.

Noether was expected to arrive on November 3 in New York, where a graduate of Bryn Mawr would meet her. On October 27, however, she cabled that her visa had been delayed. Finally, on November 7, President Park informed a reporter for the Philadelphia Record that "Dr. Emmy Noether has just arrived from Germany on the Bremen after a voyage which she greatly enjoyed." ${ }^{27}$ In this letter, Park, apparently at Noether's request, cautioned the reporter not to ask Noether too much about Germany:

[she] cannot speak of German conditions during her American residence. She has a brother and many friends in Germany and she wishes herself to return for a summer. It is clear that discreet silence on her part is necessary if she is to feel at ease about her family and insure her own return.

Apparently, Noether feared that reprisals might be taken against her family members, friends, and colleagues who were still in Germany. Upon her arrival at the college, Park also found out that Noether's "English proves to be entirely usable." ${ }^{28}$ Later that month, President Park invited distinguished mathematicians from schools in the region (including Princeton, the University of Pennsylvania, and Swarthmore) to a lecture to be given by Noether on December 15, which certainly augmented the reputation of the mathematics program at Bryn Mawr. As Tent writes in this context, "Catching' Professor Emmy Noether was a real coup for this small but respected college." 29

At Veblen's invitation, in February 1934 Noether began to give weekly lectures in Princeton-at the IAS, as she noted emphatically in her March 6, 1934, letter to Hasse, and not at the "men's university, which admits nothing female." ${ }^{30}$ Noether's letter also showed how much she had come to enjoy Bryn Mawr and its openly friendly and cordial people. She told Hasse that she was holding a seminar with three "girls" and one lecturer, in which they studied the first volume of B. L. van der Waerden's Algebra. Noether also reported that the college had even established a fellowship and scholarships in her name, and a younger Jewish mathematician, Olga Taussky, would be coming from Göttingen to Bryn Mawr as a Noether scholar.

In summer 1934, Noether went back to Germany under the impression that she could continue her work as before. At the University of Hamburg, she lectured in a seminar on the classification of Galois field extension headed by Emil Artin, her former postdoctoral student. ${ }^{31}$ According to Tent, however,

Most of her experiences that summer ... convinced Noether that she could not remain in Nazi Germany. Many of her former colleagues shunned her, fearing trouble if they were seen talking, let alone collaborating, with her. She sadly decided to remove her possessions from Göttingen. Up to this point, she had kept her apartment in Göttingen, in the hope that she could return some day. Now she realized that that would not be possible. Noether made arrangements to ship her furniture and books to Bryn Mawr, where she would be able to enjoy her own little piece of Germany. ${ }^{32}$

Gottfried Noether, her school-age nephew who showed great mathematical talent at a young age, told his aunt that he was not allowed to speak in class and that some of the other children taunted him for what they called his "Jewish nose"; he no longer had any friends and the teacher was

\footnotetext{
${ }^{27}$ Letter from Park to J. David Stern at the Philadelphia Record, November 7, 1933. See President's Office, about E. Noether.

${ }^{28}$ Letter to Dr. Weaver at the Rockefeller Foundation on November 28, 1933. See President's Office, about E. Noether.

${ }^{29}$ Tent, 148.

${ }^{30}$ Lemmermeyer and Roquette, 204.

31 "21.06.1934, Noether an Hasse," Lemmermeyer and Roquette, 75

${ }^{32}$ Tent, 152-153.
} 
siding with the other children, instead of disciplining them. ${ }^{33}$ It was not the Germany that Noether remembered.

Noether returned to Bryn Mawr with a heavy heart to begin her second year at the college. When the term opened on October 2, 1934, President Park reintroduced Noether during her convocation speech. She announced the Noether scholars and fellows who were joining Bryn Mawr that semester. In the speech, Park also addressed current events, criticizing the Right and the Left, reactionaries and radicals, fascists and communists, Hitler and Stalin. She urged the college to hold fast to its foundational principles and to its respect for human intelligence and freedom.

A small group of fellows and students formed a circle around Noether, including Dr. Marie Weiss, Dr. Olga Taussky, Dr. Grace Shover, and Ruth Caroline Stauffer. As Tent writes,

In time, Noether developed good relations with a new group of "Noether Boys," who this time turned out to be very bright young women. Like her students in Göttingen, they rapidly became as devoted to their "mother" as the "boys" in Göttingen had been. ${ }^{34}$

Noether took them to Princeton, to the October meeting of the Mathematical Society in New York, and to the biweekly graduate seminar at the University of Pennsylvania. ${ }^{35}$ Later, Grace Quinn (née Shover) fondly recalled that Emmy Noether's "lectures were delivered in broken English. She often lapsed into her native German when she was bothered by some idea in lecturing." ${ }^{36}$ Almost every close associate would later mention that Noether loved to walk and carried on passionate mathematical discussions while walking. ${ }^{37}$

Noether's initial two-year appointment was to expire in summer 1935. In early December 1934, Wheeler called Veblen at IAS and said that she and her colleagues "are extremely anxious to keep her at Bryn Mawr but have no money for the purpose." 38 Wheeler asked Veblen whether IAS could do anything to help out. On December 13, 1934, Veblen wrote to Abraham Flexner, the IAS director, to discuss this:

The professors of the Institute would be quite willing to recommend a small grant-in-aid for a year or two, especially in view of the fact that Miss Noether has been lecturing here during the last two years. And this might help to bridge the gap in case it is necessary to make temporary arrangements for a couple of years longer. In view of Miss Noether's unique position in the world-the only woman mathematician of the first order-it ought to be possible to find some persons or group of people who would make it possible for Bryn Mawr to keep her permanently. ${ }^{39}$

Indeed, simultaneous efforts were being made to secure outside funding for Noether by other mathematicians and the local Jewish community. On December 12, 1934, when Arnold Dresen, chairman of the Department of Mathematics and Astronomy at Swarthmore, met with Jacob Billikopf, the executive director of the Federation of Jewish Philanthropies in Philadelphia and the impartial chairman of the Philadelphia Regional Labor Board, they decided that Dresen would request that renowned mathematicians send letters of support to Billikopf so that the latter could help secure funds to ensure Noether's continued residence at Bryn Mawr. ${ }^{40}$ By the first week of January, Billikopf was able to inform the Emergency Committee that he could offer between $\$ 750$ and $\$ 1,000$ toward Noether's support. ${ }^{41}$ And on January 16, 1935, the Lucius N. Littauer Foundation in New York promised Bryn Mawr an additional \$1,000 for Noether.

These funds were a boon for Noether, yet she could not remain at Bryn Mawr without further support from the Emergency Committee and the Rockefeller Foundation. On January 8, Alfred Cohn, at the Emergency Committee, asked Billikopf to instruct Bryn Mawr College "to request a renewal of the existing grants from the Emergency Committee and the Rockefeller Foundation," which amounted to $\$ 2,000$ from each institution. ${ }^{42}$ Cohn indicated to Billikopf that the committee would "make a determined effort to continue to supply grants." But when Bryn Mawr's acting president, Helen Taft Manning, approached the Rockefeller Foundation, her request for a renewal of Noether's funding was all but denied. In a letter to Flexner at IAS, dated February 21, 1935, Manning explained what happened. Warren Weaver, at the Rockefeller Foundation, asked Manning

whether it was likely that the college could plan to make the appointment a permanent one, by which I take it he meant to ask whether we could put her salary on our regular budget. Unfortunately I had to write him that we had no plan by which this could be done in the immediate future because there was no

\footnotetext{
${ }^{33}$ Tent, 153.

${ }^{34}$ Tent, 147.

${ }^{35}$ Grace S. Quinn, Ruth S. McKee, Marguerite Lehr, and Olga Taussky, "Emmy Noether in Bryn Mawr," in Bhama Srinivasan, and Judith D. Sally, eds., Emmy Noether in Bryn Mawr: Proceedings of a Symposium Sponsored by the Association for Women in Mathematics in Honor of Emmy Noether's 100 th Birthday. New York: Springer Verlag (1983) 138-146, here 140.

${ }^{36}$ Clark H. Kimberling, "Emmy Noether," The American Mathematical Monthly 79:2 (1972), 136-149, here 148.

${ }^{37}$ Kimberling, "Emmy Noether," 148; "18.04.1935, M. Lehr über E. Noether," Dokumente zu Emmy Noether, 47-48.

38“13.12.1934, Veblen an A. Flexner," Dokumente zu Emmy Noether, 78.

39"13.12.1934, Veblen an A. Flexner," Dokumente zu Emmy Noether, 78.

${ }^{40}$ See President's Office, about E. Noether.

41 "21.02.1935, Manning an A. Flexner," Dokumente zu Emmy Noether, 82.

42،21.02.1935, Manning an A. Flexner," Dokumente zu Emmy Noether, 82.
} 
vacancy in the Mathematics Department and because, remarkable as are her gifts, there seems every reason to suppose that Dr. Noether would not be able to handle undergraduate work in mathematics. Even the graduate students find her work hard and her standard of what may be expected from them somewhat high. Our only hope therefore would be that some day we might have research professorships at Bryn Mawr, for one of which Miss Noether would certainly be most eligible. After I had given this somewhat negative answer to the question I received another letter from Mr. Weaver saying that in view of my statement it seemed unlikely that the Rockefeller Foundation would renew the grant. ${ }^{43}$

After Veblen learned about the exchange between Manning and Weaver, he wrote to Flexner on February 28, 1935, lamenting Manning's "unfortunate" phrasing and suggesting that Weaver might change his mind if he knew that efforts were being made to create a fund that would enable Bryn Mawr to hire Noether permanently. Veblen reported that professors at the IAS had agreed "to set aside $\$ 1,500$ to be used as a grant for Miss Noether in the year 1935-36 in case other means of support should fail," and he mentioned

the possibility that this might become a permanent commitment on the part of the Institute. There is no doubt that, apart from the uniqueness of her position as a woman mathematician, she is quite obviously one of the most important scientists who have been displaced by the events in Germany. Therefore even a permanent commitment could be nothing but creditable to the Institute. ${ }^{44}$

Three weeks after Veblen wrote to Flexner, Warren Weaver remarked in his diary that

President M. E. Park (Bryn Mawr) presents [the] case of Dr. Emmy Noether. It has become clear that N. cannot possibly assume ordinary academic duties in this country. She has no interest in undergraduate teaching, has not made very much progress with the language, and is entirely devoted to her research interests. On the other hand the Bryn Mawr authorities like and admire her, and would very much like to have her around for a further period ... There is no hope whatsoever of absorption at Bryn Mawr, but there appears to be a fair chance for absorption at the
Princeton Institute, this being an ideal disposition of the case. ${ }^{45}$

For the time being, however, Noether could remain at Bryn Mawr. Weaver noted that the Rockefeller Foundation was ready to make an exception to its policy on academic refugees "on the grounds of her unusual eminence." 46 The foundation continued to support Noether, and her appointment at Bryn Mawr was renewed for another two years.

But Noether never finished her original two-year term. On Sunday, April 14, 1935, she died suddenly of circulatory collapse following an operation to remove a large ovarian cyst at the Bryn Mawr Hospital. She had a normal recovery in the first three days after the operation, but during the early morning of the fourth day she suddenly lost consciousness and her temperature rose to 108 degrees. A cerebral blood vessel had ruptured. ${ }^{47}$ On the following day, her physician, Dr. Brooke M. Anspach, wrote to President Park that Noether

was suffering with some cerebral lesion and that the situation was hopeless ... The outcome was impossible to avoid ... Without doubt the operative procedure hastened it but of course the operation was necessary and if the tumor had not been removed it alone would have been sufficient to have caused her death. ${ }^{48}$

\section{Remembering Emmy Noether}

Emmy Noether's funeral was held at the home of President Park on Wednesday, April 18. ${ }^{49}$ All the members of Bryn Mawr College who had known Noether, her students at Bryn Mawr, and a large number of faculty and students from the mathematics department at Princeton University attended the funeral. Professor Wheeler spoke on behalf of Bryn Mawr College, and Dr. Taussky spoke on behalf of Noether's foreign students. Hermann Weyl and Richard Brauer also spoke extemporaneously in German on behalf of her German colleagues.

The director of IAS, Abraham Flexner, wrote to President Park on April 25,

Her death has shed a deep gloom over us all, but it ought to make you and Mrs. Wheeler happy to know that a few weeks ago she remarked to Professor Veblen that the last year and a half had been the very

\footnotetext{
43“21.02.1935, Manning an A. Flexner," Dokumente zu Emmy Noether, 82.

44"28.02.1935, Veblen an A. Flexner," Dokumente zu Emmy Noether, 84-85.

45 Weaver's diary entry of March 20, 1935, is quoted in Kimberling, "Emmy Noether and Her Influence," 36-37. The "fair chance for absorption" at IAS may on some level be a reference to the possibility of opening IAS membership to women. It was not until 1936 that the archaeologist Hetty Goldman, who earned her BA from Bryn Mawr College, became the first woman appointed as professor at the IAS. (See Seymour Sy Brody, Jewish Heroes and Heroines of America: 151 True Stories of Jewish American Heroism. Hollywood, FL: Frederick Fell Publishers, 2004, 93.) If Noether hadn't died suddenly, she might have been the first professor appointed at IAS.

${ }^{46}$ Kimberling, "Emmy Noether and Her Influence," 37.

${ }^{47}$ Letter from M.D. James L. Richards addressed to President Park, dated April 24, 1935.

${ }^{48}$ See President's Office, about E. Noether.

${ }^{49}$ According to the May 16, 1935, letter from President Park to Emmy Noether's brother, Fritz Noether.
} 


\section{BRYN MAWR COLLEGE}

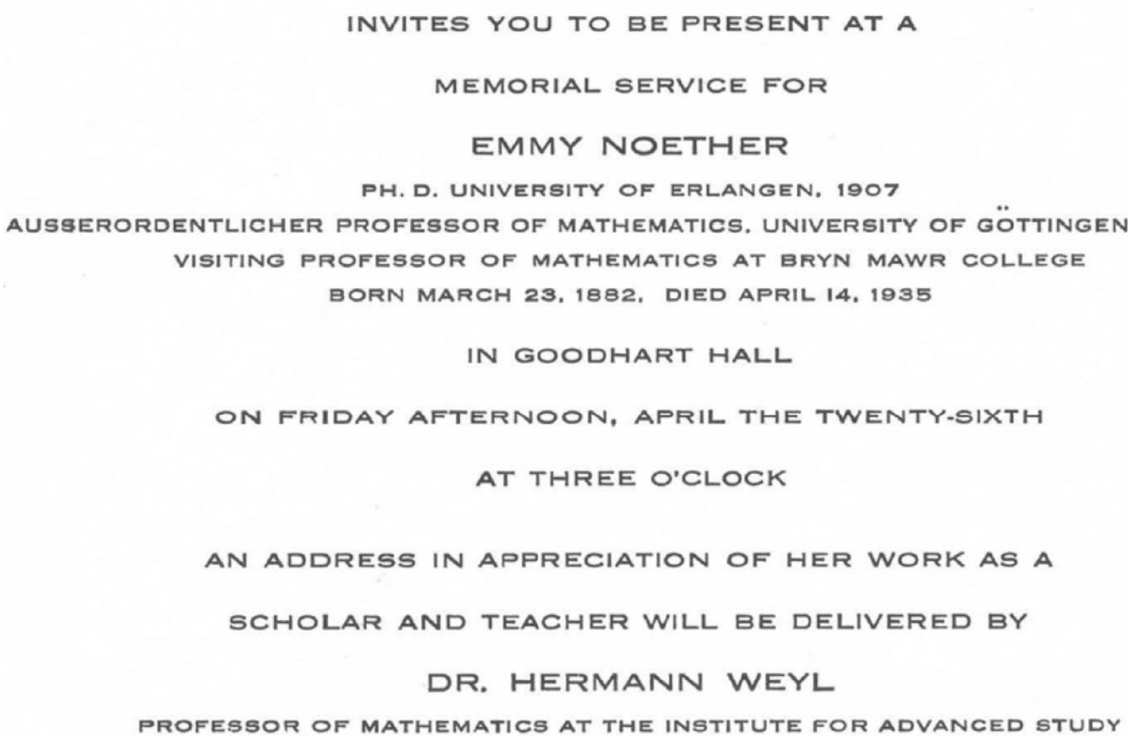

Figure 7. Invitation to a memorial service for Noether at Bryn Mawr College (courtesy of Bryn Mawr Special Collections).

happiest in her whole life, for she was appreciated in Bryn Mawr and Princeton as she had never been appreciated in her own country. ${ }^{50}$

On April 26, a memorial service was held at Goodhart Hall, where Weyl delivered an address (Fig. 7). ${ }^{51}$ Einstein also paid tribute by writing to the New York Times (May 5, 1935):

Fräulein Noether was the most significant creative mathematical genius thus far produced since the higher education of women began. In the realm of algebra, in which the most gifted mathematicians have been busy for centuries, she discovered methods which have proved of enormous importance in the development of the present-day younger generation of mathematicians. ${ }^{52}$

The urn containing her ashes was interred in the Cloisters at Bryn Mawr (Fig. 8).

Noether's death hit Ruth Stauffer, her only doctoral candidate at Bryn Mawr, especially hard. On April 8, 1935, Noether wrote her report on Ruth's dissertation:

This thesis gives some very interesting results in the field of Modern Algebra, and it has shown that Miss Stauffer has a thorough knowledge of the modern theories and that she has a feeling for abstract methods. I consider this thesis is satisfactory as a

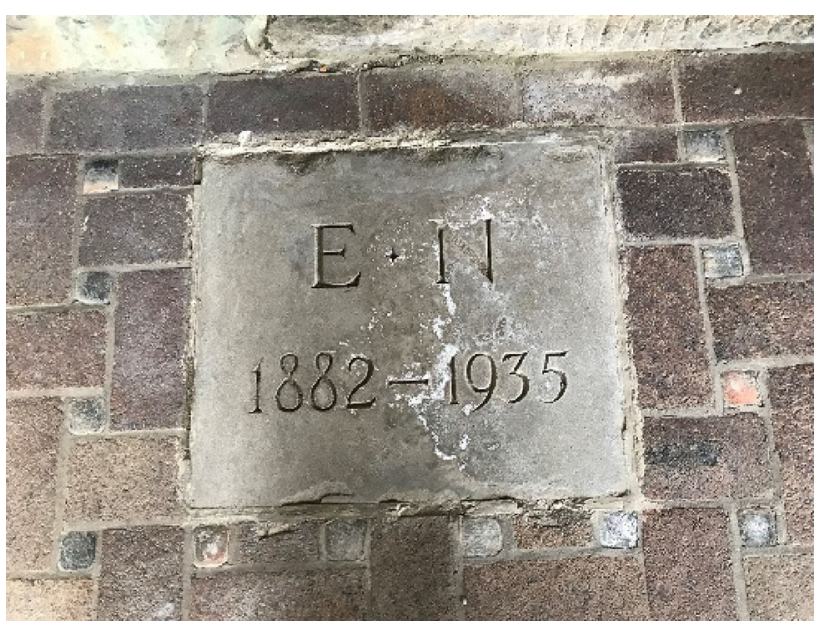

Figure 8. Noether's urn was buried in the Cloisters at Bryn Mawr College under an inconspicuous cement slab bearing only her initials (Photo: author).

partial fulfillment of the requirements for the Ph.D degree. ${ }^{53}$

Noether made it known that she would not travel before the end of June so that she would be present to confer the doctorate upon Ruth at commencement. Ruth finished her degree with Richard Brauer, but eventually left the

\footnotetext{
${ }^{50}$ See President's Office, about E. Noether; see also Dokumente zu Emmy Noether, 50.

${ }^{51}$ Weyl's memorial address was published in Scripta mathematica III, 3 (1935) 201-220. Reprinted in Dick 112-152. .

${ }^{52}$ Michael Cavna, "Emmy Noether Google Doodle: Why Einstein Called Her A 'Creative Mathematical Genius,'” March 23, 2015. https://www.washingtonpost.com/news/ comic-riffs/wp/2015/03/23/emmy-noether-google-doodle-why-einstein-called-her-a-creative-mathematical-genius/?noredirect=on\&utm_term=.213b801d7c81; "04.05. 1935, Nachruf auf E. Noether, von Einstein," Dokumente zu Emmy Noether, 87-88.

53“08.04.1935, Gutachten Stauffer, von E. Noether," Dokumente zu Emmy Noether, 43.
} 


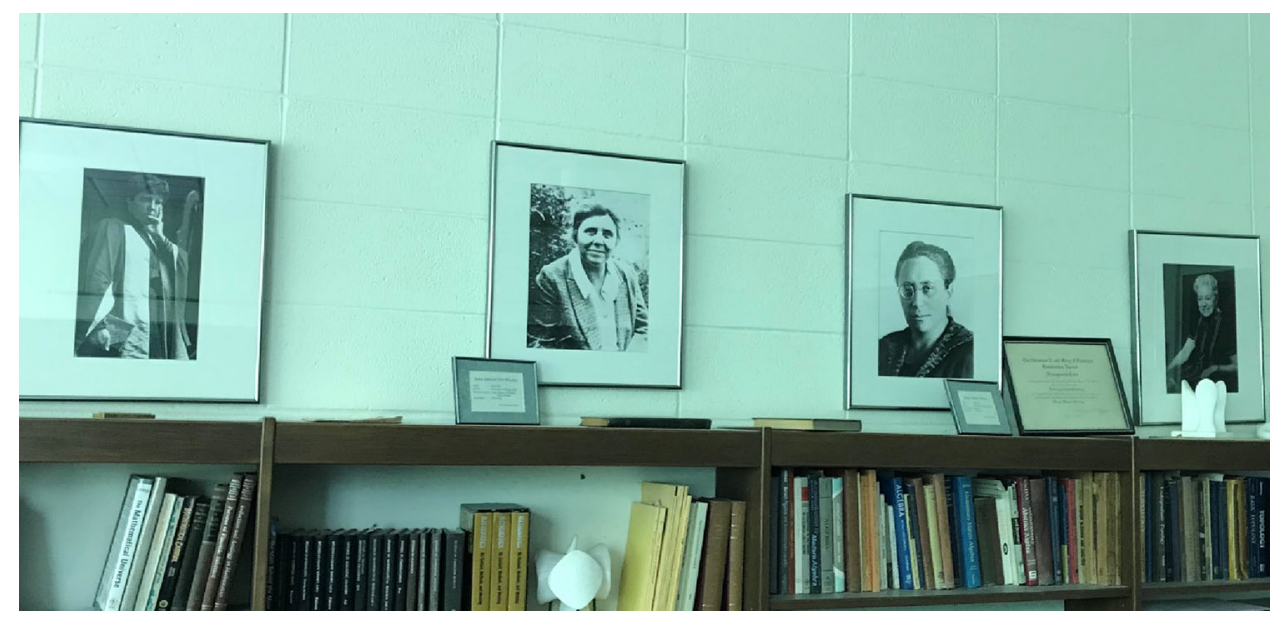

Figure 9. Portraits of Charlotte Angas Scott, Anna Pell Wheeler, Emmy Noether, and Marguerite Lehr line the wall of the seminar room of the Bryn Mawr mathematics department (Photo: author).

profession. ${ }^{54}$ Years later, she shared her recollections of her mentor:

As I remember Miss Noether's methods of thinking and working, they were simply a reflection of her way of life; that is, recognize the unessentials, brush them aside and enter whole heartedly into the present. This was, as you all know, far from a superficial achievement on the part of Miss Noether. Bitterness and jealousy were rejected by her as unessential. There was never any indication of bitterness toward Germany even though Hitler's government denied her the right to teach at Göttingen. Nor was there any sign of jealousy because of her treatment as a woman even in the end when her colleagues from Göttingen went to the Institute for Advanced Study at Princeton with possibilities of many promising advanced young students. Her lot, instead, was Bryn Mawr, with a Mathematics Department consisting of four faculty members headed by Mrs. Wheeler and five graduate students who had never been exposed to any abstract algebra. She knew, of course, that there was a possibility of trips to Princeton for lectures and discussions. ${ }^{55}$

Noether's brother, Fritz Noether, as well as her cousin in Mannheim, Otto Nöther, expressed their gratitude to Bryn Mawr for having become "a second home" (eine zweite Heimat) to Emmy. ${ }^{56}$ Fritz Noether wrote on May 23, 1935 , to Professor Wheeler:
I know also from other reports that she felt at home at Bryn Mawr, and Bryn Mawr had become an absolute substitute for what she had to give up in her homeland. I also see from your report, how well you all know her, her idiosyncrasies, and her main traits-the unbreakable optimism which she evidently held till the last hours. Painful as the thought is to us all that she is no longer here with us, the greatest satisfaction remains that she herself kept living and working in her ideas until the moment that her thinking stopped, without her becoming aware of it. ${ }^{57}$

Today, in the seminar room of Bryn Mawr's math department, a portrait of Noether hangs alongside those of Charlotte Angas Scott (1858-1931), the college's first mathematician and the founder of the department, and Noether's colleagues Anna Pell Wheeler and Marguerite Lehr (1898-1987) (Fig. 9). ${ }^{58}$ Looking back on the mathematical tradition at Bryn Mawr, historian of mathematics William Dunham wrote, "I can say with confidence that no other math department in the U.S. can boast a stronger, more distinguished line-up of women mathematicians."

The house in the Erlangen Hauptstraße in which Noether was born is still standing. A commemorative plaque has been placed near the entrance (Fig. 10).

\section{Bryn Mawr as a Haven for Refugees}

Emmy Noether was the star academic Bryn Mawr snagged from Nazi Germany. In addition, Bryn Mawr hosted a number of other refugee scholars, including Dr. Eva Fiesel,

\footnotetext{
${ }^{54}$ Dick, 85-86.

${ }^{55}$ Quinn, McKee, Lehr, and Taussky, 143.

${ }^{56}$ See President's Office, about E. Noether; see also Dokumente zu Emmy Noether, 57-59.

${ }^{57}$ My translation. See President's Office, about E. Noether; see also Dokumente zu Emmy Noether, 56.

${ }^{58}$ Karen Hunger Parshall, "Training Women in Mathematical Research: The First Fifty Years of Bryn Mawr College (1885-1935)," Mathematical Intelligencer 37:2 (2015), 71-83.

${ }^{59}$ Email communication on March 23, 2018. William Dunham is a research associate in mathematics at Bryn Mawr College; see also Dunham's discussion of these women mathematicians at the beginning of his article, "Bertrand Russell at Bryn Mawr," Mathematical Intelligencer 38:3 (2016), 30-40.
} 


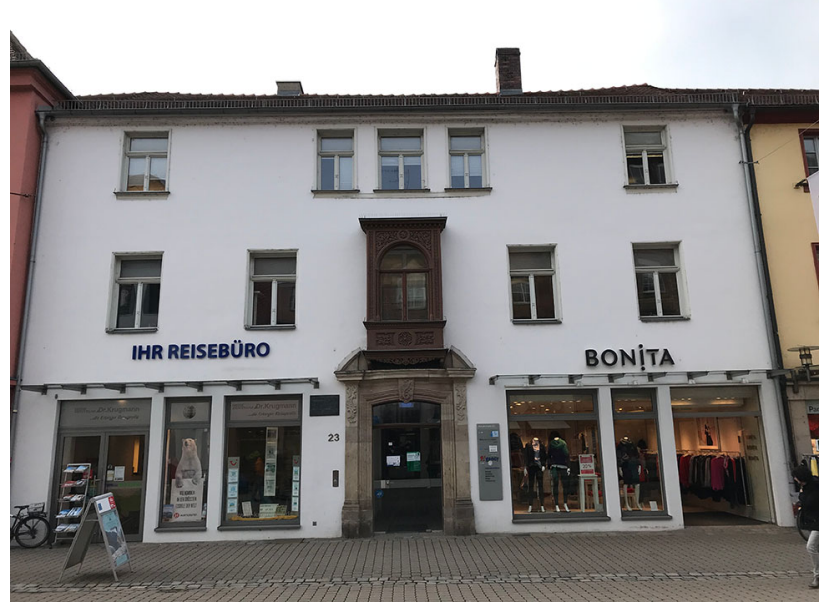

Figure 10. Birthplace of Emmy Noether, Erlangen Hauptstraße, Erlangen, Germany (Photo: author).

an Etruscan scholar; Hertha Kraus, professor of social work and social research; Richard Bernheimer, professor of art history; Dr. Hilda Pollaczek Geiringer, an expert on theoretical statistics; Fritz Karsen, professor of education; and Felix Gilbert, professor of history. In 1941, looking back on Bryn Mawr's role as a host to displaced academics, President Park wrote, "The college has on the whole had excellent experience with refugee scholars ... from the point of view of teaching and adaptation to the community."60

The archival material concerning Bryn Mawr's cooperation with the Emergency Committee indicates that the college was very invested in assisting displaced scholars from Europe, especially female academics, at a time when academia was not as open to women as it is today. In total, Nazi Germany banned around 12,000 scholars from their profession. The Emergency Committee received close to 6,000 applications. Although only 330 received aid from the committee, many more scholars made it to the United States and other safe havens through other means. Out of the eighty women scientists and mathematicians who found refuge in the United States identified by researchers at Northeastern University, only four were supported by the committee, including Emmy Noether and Hilda Geiringer, both of whom accepted positions at Bryn Mawr. ${ }^{61}$ The college provided a hospitable environment under the great leadership of President Park.

The migration of these scholars represented a massive brain drain for Germany and a great gain for America. Only with the invigoration of these European scholars did Princeton, for example, attain comparable excellence with other major mathematical centers. ${ }^{62}$ Germany's loss of these scholars to America attested to the consequence Nazi Germany had to bear due to its myopic bigotry and racism. When asked by the new Nazi minister of education, Wilhelm Rust, how mathematics at the University of Göttingen was progressing now that the Jews had been cleansed from the faculty, David Hilbert replied bitterly, "Mathematics in Göttingen? There is really none anymore." 63 Göttingen had forever lost its glory as the "mecca of mathematics of the time." ${ }^{64}$ The displaced scholars went on to make a huge contribution to the development of science and academic disciplines in the United States. Emmy Noether is a paragon of women's intellectual capacity and academic prowess, and she continues to inspire young women at Bryn Mawr and beyond even today.

\section{ACKNOWLEDGMENTS}

An earlier version of this essay was presented as part of the panel "Refugee Scholars from Nazi Germany to the Tri-Co" during a Community Day of Learning at Bryn Mawr College on March 20, 2018, which focused on the theme "Being Bryn Mawr: Past, Present, and Future." I want to thank my student Stephanie Strevey ('21) and Prof. David Cast, in Art History, for joining me on the panel. I want especially to thank Eric Pumroy, director of the Department of Special Collections at Bryn Mawr Library, for his generous help with locating and digitalizing archival files for this project, and Jane Epstein, assistant secretary of Bryn Mawr College, for pointing me to Abraham Flexner's personal connections to Bryn Mawr and her encouraging support of this project. This article has been an investigative journey of discovery in which I have tried to pull together all the threads pertaining to Noether and Bryn Mawr College. And I am immensely grateful to Gene McGarry for his thorough reading, which pushed me to write a coherent story and solve as many puzzles as possible.

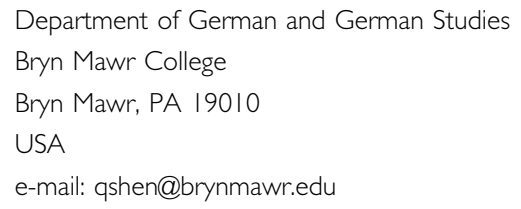

\footnotetext{
${ }^{60}$ Letter to President John Nason of Swarthmore and President Felix Morley of Haverford on February 12, 1941.

${ }^{61}$ Boissoneault.

${ }^{62}$ Saunders Mac Lane, "Mathematics at the University of Göttingen 1931-1933," in Brewer and Smith, 65-78, here 65.

${ }^{63}$ Tent, 146.

${ }^{64}$ Tent, 56
} 